\title{
Multiple Endocrine Neoplasia Type 1 with Unusual Concomitance of Various Neoplastic Disorders
}

\author{
YOSHIHIRO NISHIMURA*, KOH YAMASHITA*, WATARU YUMITA*, MASANORI YAMAZAKI*, \\ MIYUKI KATAI*, AKIHIRO SAKURAI*,** AND KIYOSHI HASHIZUME* \\ *Department of Aging Medicine and Geriatrics, Shinshu University Graduate School of Medicine, Matsumoto, Japan \\ **Division of Medical Genetics, Department of Preventive Medicine, Shinshu University School of Medicine, Matsumoto, Japan
}

\begin{abstract}
A patient with multiple endocrine neoplasia type 1 (MEN1) who manifested various MEN1-unrelated tumors was reported. The patient was a 43-year-old woman who manifested typical features of MEN1 including primary hyperparathyroidism, prolactinoma, adrenal adenoma and visceral lipomas. During the course, she also manifested chondrosarcoma, B cell lymphoma and mesothelioma. The patient had no apparent family history of MEN1 or any other neoplastic diseases. Genetic analysis of DNA from peripheral mononuclear cells of the patient revealed no germline mutations in MEN1 gene. Genetic instability due to yet unidentified cause is the possible explanation of occurrence of multiple tumors. Careful periodic screening of endocrine and other disorders for her siblings and children as well as for the patient is warranted.
\end{abstract}

Key words: MEN1, Hyperparathyroidism, Prolactinoma, Cushing's syndrome, Chondrosarcoma, Lymphoma, Mesothelioma (Endocrine Journal 51: 75-81, 2004)

OCCURRENCE of two or more endocrine tumors in one patient is caused by genetic disorders in most cases. Such well recognized syndromes as multiple endocrine neoplasia type 1 (MEN1), MEN2, von HippelLindau disease and Carney's complex [1], are caused by germline mutations of the responsible genes, MEN1, RET, VHL, and PRKAR1A, respectively, and are inherited in an autosomal dominant manner with high degree of penetrance. Identification of those responsible genes rapidly changed the standard procedure of screening for family members from conventional biochemical measurement and radioimaging to more reliable genetic tests which allow detection of gene carriers before their clinical symptoms develop. Beside those genetic syndromes, concurrence of multiple endocrine tumors in one patient is occasionally ob-

Received: August 25, 2003

Accepted: October 30, 2003

Correspondence to: Akihiro SAKURAI, M.D., Ph.D., Division of Molecular Genetics, Department of Preventive Medicine, Shinshu University School of Medicine, 3-1-1 Asahi, Matsumoto 3908621, Japan served, but its etiology is largely unknown with exception of McCune-Albright syndrome that manifests various endocrine tumors due to activating mutation of the GNAS1 gene during early embryogenesis, which results in somatic mosaicism [2].

MEN1 (OMIM \#131100) is a hereditary syndrome characterized by predisposition to hyperplastic and neoplastic disorders arising predominantly from endocrine organs such as parathyroids, anterior pituitary and endocrine pancreas [3]. Clinical diagnosis of MEN1 can be made by confirmation of at least two neoplastic lesions in three of the target organs. Besides those three principal lesions, other disorders such as adrenal cortex tumors, foregut carcinoid tumors and dermal lesions are also seen. Heterozygous germline mutations of the MEN1 gene have been identified in over $90 \%$ of patients with MEN1 and until now, more than 300 germline MEN1 gene mutations have been reported. Subjects with MEN1 without either family history or MEN1 germline mutations are occasionally observed, of which clinical features have been reported by Hai et al. and Burgess et al. [4, 5]. According to the former, most of such patients were female and 
combination of hyperparathyroidism and GH secreting pituitary tumors was frequently observed especially in relatively older subjects, while enteropancreatic tumors were infrequent. The latter reported on subjects of MEN1 phenocopy identified in large MEN1 kindred. Both reports speculate that concurrence of relatively common endocrine tumors, hyperparathyroidism and pituitary tumors, in MEN1 phenocopy patients is likely coincidental.

We have recently encountered a patient with MEN1 who had no apparent family history. Germline mutation of the MEN1 gene was not identified despite expression of typical clinical features of MEN1. Interestingly, this patient manifested various non-endocrine tumors as well as MEN1-related tumors. We here report clinical and genetic features of this case.

\section{Case report}

The patient was a 43-year-old woman who was admitted to the orthopedic division of our hospital because of a dislocation of hip joint and severe osteoporosis. She was referred to us for evaluation of endocrine disorders in June, 2000. She had a history of repeated surgeries for bowel obstruction due to multiple visceral lipomas at ages of 37 and 43 . No endocrine- and bone diseases have been noticed in her parents, nor does her younger sister, 42 years old, have any recognized endocrine disorders. On physical examination, she was $157 \mathrm{~cm}$ tall and weighed $62 \mathrm{~kg}$, and had clinical Cushingoid features such as central obesity, hypertension, moon face and thin skin. Subsequent laboratory and radiological examinations revealed she had primary hyperparathyroidism, prolactinoma and a left adrenal adenoma (Table 1, Fig. 1). The diagnosis of MEN1 was thus made. Galactorrhea was not seen. Computed tomography of the abdomen also revealed multiple liver cysts and a pancreatic cyst. Ultrasound examination of the neck revealed enlarged parathyroid glands and intrathyroidal nodular lesions, the latter being diagnosed as an adenomatous goiter. Levels of serum glucagon, gastrin, secretin and pancreatic polypeptide were within normal range. Despite glucocorticoid excess due to adrenal adenoma, levels of fasting plasma glucose $(91 \mathrm{mg} / \mathrm{dL})$ and serum in-

Table 1. Laboratory data of the patient

\begin{tabular}{|c|c|c|c|c|c|c|}
\hline & Jun. 2000. & Nov. 2001. & Nov. 2002. & Jan. 2003. & Jun. 2003. & Normal range \\
\hline Total protein & 6.6 & 7.0 & 6.1 & 6.7 & 6.8 & $6.8-8.3(\mathrm{~g} / \mathrm{dl})$ \\
\hline Albumin & 4.0 & 4.2 & 3.5 & 4.0 & 3.9 & $4.2-5.1(\mathrm{~g} / \mathrm{dl})$ \\
\hline Creatinine & 0.5 & 1.1 & 0.9 & 0.9 & 0.8 & $0.4-0.8(\mathrm{mg} / \mathrm{dl})$ \\
\hline Calcium & 11.7 & 10.0 & 9.8 & 9.7 & 10.3 & $8.6-10.1(\mathrm{mg} / \mathrm{dl})$ \\
\hline Phosphate & 2.3 & 2.9 & 2.7 & 3.0 & 3.6 & $2.2-4.1(\mathrm{mg} / \mathrm{dl})$ \\
\hline Intact PTH & 170 & & & & $<5$ & $14-66(\mathrm{pg} / \mathrm{ml})$ \\
\hline Prolactin & 114.9 & 88.1 & 172.7 & & 134.1 & $1.4-14.6(\mathrm{ng} / \mathrm{ml})$ \\
\hline 17-OHCS & 14.0 & & $2.5^{2)}$ & & & $1.6-8.8$ (mg/day) \\
\hline ACTH & $6.8 / 2.4 / 7.7^{1)}$ & & $\left.4.3 /-/-^{2}\right)$ & & & $9-60(\mathrm{pg} / \mathrm{ml})$ \\
\hline Cortisol & $17.1 / 16.8 / 17.4^{1)}$ & & $\left.1.6 /-/-^{2}\right)$ & & & $5-15(\mu \mathrm{g} / \mathrm{dl})$ \\
\hline WBC & 8,630 & 6,500 & 11,650 & 12,290 & 31,980 & $3,500-9,800(/ \mu \mathrm{l})$ \\
\hline Seg $(\%)$ & 59 & 54 & 53 & 50 & 43 & \\
\hline Band (\%) & 2 & 0 & 0 & 2 & 2 & \\
\hline Mono (\%) & 10 & 8 & 14 & 11 & 3 & \\
\hline Eos $(\%)$ & 1 & 4 & 2 & 3 & 2 & \\
\hline Baso (\%) & 0 & 0 & 0 & 1 & 0 & \\
\hline Lym (\%) & 28 & 0 & 5 & 10 & 3 & \\
\hline $\mathrm{Ab} .{ }^{3)}(\%)$ & 0 & 34 & 26 & 23 & 47 & \\
\hline $\mathrm{RBC}$ & 4.83 & & 4.19 & 4.00 & 3.92 & $3.75-5.01\left(\times 10^{6} / \mu 1\right)$ \\
\hline Hemoglobin & 14.7 & & 12.2 & 11.8 & 11.7 & $11.1-15.1(\mathrm{~g} / \mathrm{dl})$ \\
\hline CRP & & & 0.01 & 0.05 & 0.04 & $<0.10(\mathrm{mg} / \mathrm{dl})$ \\
\hline
\end{tabular}

\footnotetext{
1) Results of daily profile. Samples were obtained at 7:00/14:00/23:00.

2) Patient has been taking $0.5 \mathrm{mg}$ dexamethasone.

3) Abnormally shaped mononuclear cells of B-cell origin.
} 
A.

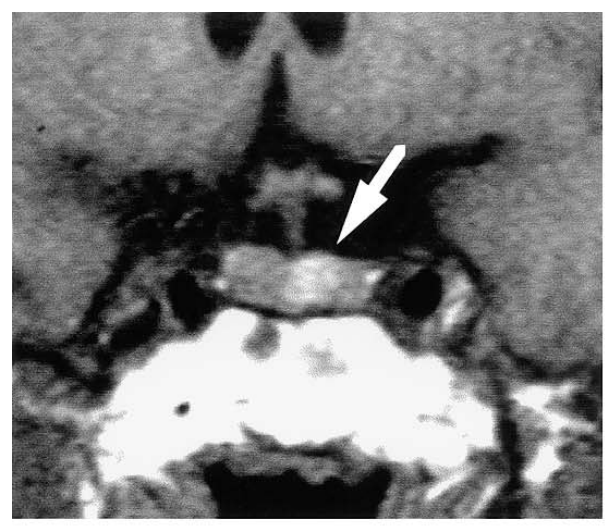

B.

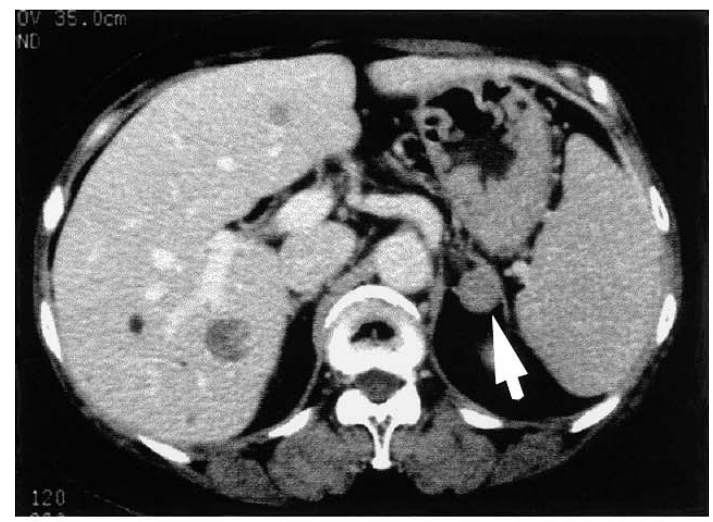

\section{C.}

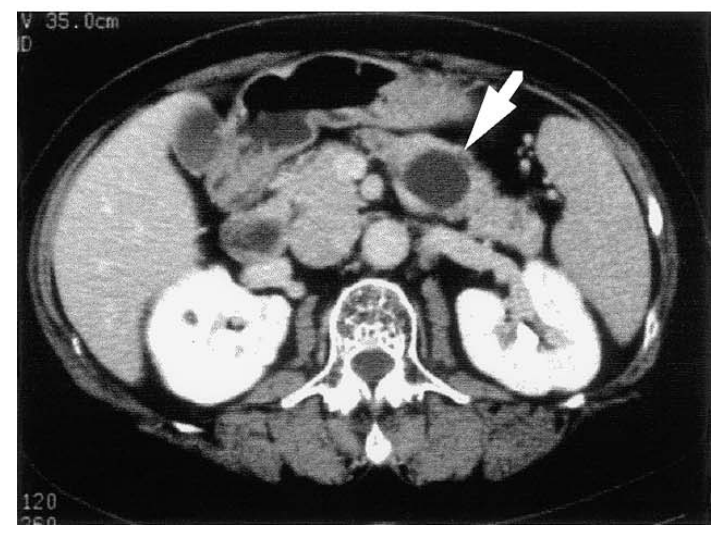

Fig. 1. A) T1-weighted MRI of the pituitary gland demonstrating a microadenoma (arrow). B) CT scan of the abdomen demonstrating a left adrenal tumor (arrow). Multiple hemangiomas and cysts of the liver and splenomegaly are also seen. C) CT scan of the abdomen demonstrating a cyst at pancreas body (arrow).

sulin $(3.2 \mathrm{mU} / \mathrm{L})$ were within normal range. Oral glucose tolerance test was not performed. Levels of tumor markers, $\alpha$-fetoprotein, carcinoembryonic antigen and CA19-9 were not elevated and results of hematology were unremarkable (Table 1). Laparoscopic
A.

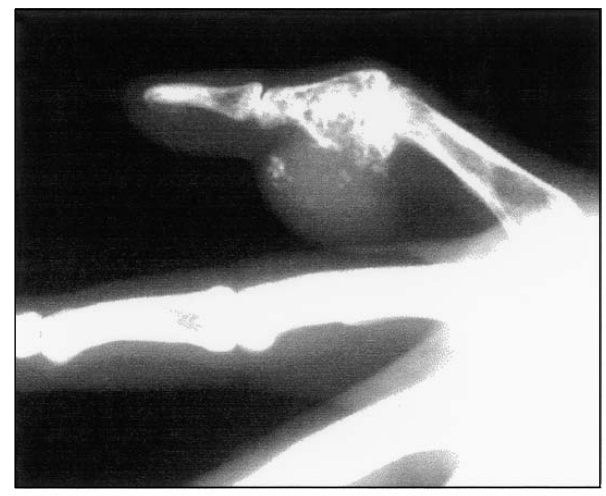

B.

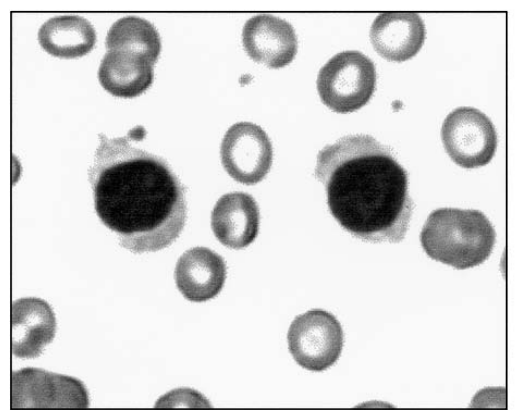

Fig. 2. A) X-ray image of the right fingers. A round and solid tumor accompanies destruction and abnormal ossification of middle phalanx of the 5th finger. Calcification in the tumor is also seen. B) Abnormal lymphoma cells seen in peripheral blood smear.

left adrenalectomy and total parathyroidectomy with autotransplantation were performed in August and September, 2000, respectively. On pathological examination of surgically resected specimens, adrenal tumor was typical cortisol-producing adenoma and no aggressive features were seen. All four parathyroid glands were hyperplastic. The size of each gland was $23 \times 9 \mathrm{~mm}$ (left upper gland), $30 \times 12 \mathrm{~mm}$ (left lower gland), $15 \times 8 \mathrm{~mm}$ (right upper gland) and $15 \times 7 \mathrm{~mm}$ (right lower gland). Soon after operations for the left adrenal tumor and hyperplastic parathyroids, which rendered adrenal function and serum calcium level to within normal range, respectively, she noticed a painful mass at the right 5th finger. Pathological examination of biopsy specimen revealed this tumor as chondrosarcoma and amputation of the finger was performed in May, 2001 (Fig. 2A). During the same year, hematologic examination revealed appearance of abnormally shaped mononuclear cells with cytoplasmic projections (Table 1, Fig. 2B). Peripheral lymphadenopathy was not seen but splenomegaly $(15.5 \mathrm{~cm} \times 6.6 \mathrm{~cm})$ progressed. Bone marrow aspira- 
Table 2. Immunophenotypic profile of peripheral lymphocytes

\begin{tabular}{lccclc}
\hline \multicolumn{2}{c}{ T cell lineage } & \multicolumn{2}{c}{ B cell lineage } & \multicolumn{2}{c}{ Others } \\
\hline CD2 & - & CD10 & + & CD11b & + \\
CD3 & - & CD19 & + & CD11c & + \\
CD4 & - & CD20 & + & CD13 & - \\
CD5 & - & CD22 & + & CD14 & - \\
CD7 & - & s-IgA & $0 \%$ & CD25 & - \\
CD8 & - & s-IgM & $48 \%$ & CD38 & - \\
& & s-IgG & $11 \%$ & CD103 & - \\
& & s-IgD & $1 \%$ & & \\
& & $\kappa$ & $1 \%$ & & \\
& & $\lambda$ & $51 \%$ & & \\
\hline
\end{tabular}

tion revealed normal marrow cellularity with small fraction (2.4\%) of abnormal lymphocytes. Profiles of surface marker of peripheral lymphocytes (Table 2) indicated that abnormal cells were $\mathrm{B}$ cell origin and were relatively matured. Tartrate-resistant acid phosphatase (TRAP), pathognomonic of hairy cell leukemia, was positive only in small number of cells. Karyotype analysis of peripheral lymphocytes (34\% abnormal cells) revealed no gross abnormalities. Whole body gallium scintiscan was negative. White cell count gradually increased during follow-up, although proportion of abnormal cells remained constant. She also complained of left flank pain and a low grade fever $\left(37.0-38.0^{\circ} \mathrm{C}\right)$. She received splenectomy in April, 2003, that relieved her from flank pain but not from low grade fever and leukocytosis. Pathology of the spleen revealed diffuse proliferation of B cells. Blood lake in the spleen, a highly specific finding in hairy cell leukemia [6], was not seen. During operation, a tumor in the omentum was incidentally found and removed, which was pathologically diagnosed as mesothelioma.

To genetically confirm the diagnosis of MEN1, germline MEN1 gene mutation of the patient was examined after written informed consent had been obtained. This study was reviewed and approved by the Ethics Review Committee for Human Gene Analysis Research of Shinshu University. High-molecular-weight DNA was isolated from peripheral mononuclear cells and the entire coding region of the MEN1 gene was amplified and directly sequenced as has been described [7]. Germline mutations were not found. Two intragenic polymorphisms, D418D (GAC/GAT) and A541T (GCA/ACA), were heterozygous [8]. We then asked if MEN1 gene locus is lost in tumors of this patient as is seen in tumors from MEN1 subjects and also
Table 3. Effect of diepoxybutane on survival of mononuclear cells

\begin{tabular}{cccc}
\hline & Patient & Control & p value \\
\hline Cell survival (\%) & $34 \pm 11$ & $64 \pm 11$ & $<0.05$ \\
\hline
\end{tabular}

Experimental procedure has been described previously [12]. Results are mean \pm S.E. of four determinations. Note that patient's mononuclear cells contained $34 \%$ of lymphoma cells (blood sample was obtained in Nov. '01). See Table 1 for hematological analysis.

in about one-third of sporadic parathyroid- and adrenal tumors $[9,10]$. DNA was isolated from left lower parathyroid tumor and adrenal tumor and heterozygosity of two polymorphic sites were examined by direct sequencing. Heterozygosity of two sites was conserved in both tumors, indicating that gross deletion of the MEN1 gene locus did not occur in either allele.

We also examined if the patient possessed genetic instability. We have previously reported that mononuclear cells from patients with MEN1 show enhanced sensitivity to alkylating agent, diepoxybutane, but not to ultraviolet $[11,12]$. Mononuclear cells were isolated from peripheral blood and cultured in 24-well plate. Twenty-four hours later, $3 \mathrm{nM}$ of diepoxybutane was added to culture medium and the viability of cells was culculated 6 days later [12]. The survival of patient's lymphocytes was significantly lower than that of normal subjects (Table 3 ).

\section{Discussion}

In this study, we reported a case with MEN1 who manifested various neoplastic disorders other than classical MEN1 lesions during the last several years. She has no personal history of exposure to excessive irradiation or chemicals and no subjects with endocrine disorders were found in her family. Genetic analysis revealed no MEN1 germline mutation.

Patients with MEN1 who have no family history or MEN1 germline mutations are occasionally recognized. Hai et al. reported the clinical features of such patients to include the commonly seen combination of primary hyperparathyroidism due to parathyroid adenoma and GH producing pituitary tumor, and the relatively older age of such patients than genetically confirmed MEN1 patients [4]. In contrast, the clinical features of our patient were those of typical MEN1 
including four-gland parathyroid hyperplasia, prolactinoma, adrenal cortex tumor and visceral lipomas. Therefore it was unexpected for us that we could not find MEN1 germline mutation in this patient. Sensitivity to detect $M E N 1$ gene mutation in affected patients is more than $90 \%$ and large deletion of the MEN1 gene is reported in some families [13, 14]. Although deletion or abnormal methylation of the part of the MEN1 gene or mutation in the promoter region cannot be excluded, retention of two alleles in the tumors as well as peripheral mononuclear cells makes those possibilities less likely, and these results strongly argue against possible involvement of MEN1 gene in the tumorigenesis in our patient.

The intriguing finding in our patient was the concomitant occurrence of various neoplastic diseases seemingly unrelated to MEN1. Chondrosarcoma consists about $20 \%$ of all bone sarcomas and is seen predominantly in flat bones. Most cases are sporadic but some hereditary syndromes including multiple exostoses and Maffucci syndrome are known to cause chondrosarcoma [15]. Maffucci syndrome is a rare disorder characterized by multiple osteochondromatosis which sometimes transforms to chondrosarcoma. Patients with Maffucci syndrome sometimes have accompanying endocrine tumors such as pituitary adenoma, thyroid adenoma and ovarian tumor $[16,17]$. Concurrence of Maffucci syndrome and MEN1 has also been reported [18]. Maffucci syndrome is caused by a mutation in the PTH/PTHrP type 1 receptor gene PTHR1 [19] but pathogenesis of endocrine disorders in this syndrome is unknown. In our patient, however, clinical pictures are apparently different from those of Maffucci syndrome as bone lesions seen in Maffucci syndrome is usually multiple and appear during childhood, but clinically stabilizes after puberty. Tubular bone deformity is almost exclusively seen in Maffucci syndrome. Our patient showed no skeletal abnormalities other than compression fractures of thoracic and lumbar spine probably due to glucocorticoid-induced osteoporosis.

Our patient also manifested B cell lymphoma with atypical morphological features that resemble to those of hairy cell leukemia. Hairy cell leukemia is a relatively uncommon B-lymphoproliferative disease which comprises about $2 \%$ of all leukemias and shows malepredominant occurrence [6]. Diagnosis of hairy cell leukemia is usually straightforward based on characteristic morphology of leukemic cells, positive TRAP stain and immunophenotypes such as expression of CD11c, CD19, CD20, CD25 and CD103 [6]. Chromosome rearrangements are frequently, but not always, seen [20]. In our patient, leukemic cells showed some features compatible with hairy cell leukemia, but did not come to the final diagnosis because of the lack or weakness of other chemical, immunological and karyotypic features.

The molecular background of occurrence of multiple tumors in our patients is currently unknown, but the following possibilities could be considered. The first possibility is that genetically independent tumors occurred by chance. This is unlikely considering the number and variety of tumors developed in the patient. All tumors found in our patient were relatively rare and such a possibility would be extremely low. The presence of a common genetic or environmental background for development of those tumors is a more tenable proposition. The second possibility is that the patient could have a MEN1 like syndrome with low penetrance that was caused by yet unknown genetic factors. This speculation is applicable to all patients who have MEN1 phenotype but have no detectable MEN1 gene mutation. The molecular function of the MEN1 gene product, menin, has been extensively studied since isolation of this gene. Menin is a 610 aminoacid nuclear protein that interacts with various nuclear and cytoplasmic proteins including JunD, NF-kB, Smad3, Pem, Nm23, RPA2, and vimentin [21, 22]. Smad1, Smad5 and FANCD2 are recent additions to the family of menin-interacting proteins [23, 24]. Although the physiological relevance of these interactions has not been clarified, it is possible that our patient has a defect in some of those proteins or the downstream components of signal transduction mediated by those proteins. Targeted disruption of genes for those menin-interacting proteins, however, does not produce MEN1-like phenotypes in mice [25-29]. At this moment, we are unable to point possible common factor(s) that can explain the concomitant occurrence of MEN1, chondrosarcoma, B cell lymphoma and mesothelioma in our patient. The third possibility is that the patient has a status of genetic instability that triggered tumorigenesis in various organs. This possibility is an attractive one since several syndromes with genetic instability are known to be characterized by predisposition to various tumors $[30,31]$. We therefore examined the sensitivity of patient's lymphocytes to alkylating agent compared to those from normal 
control, and results were at least in part supportive of this view (Table 3). However, we are cautious to conclude the presence of genetic instability in our patient and to attribute it to occurrence of multiple tumors, since the peripheral lymphocytes we examined contained a considerable proportion of lymphoma cells.

In conclusion, we reported a very unusual case with typical MEN1 phenotype accompanied by rare neoplastic disorders. Although the molecular mechanisms of tumorigenesis in our patients is yet uncertain, we need to consider the necessity of continuing careful periodic screening of endocrine and other disorders for her sister and children as well as for the patient.

\section{References}

1. Gagel RF, Marx SJ (2002) Multiple endocrine neoplasia. In: Larsen PR, Kronenberg HM, Melmed S, Polonsky KS (eds) Textbook of Endocrinology. WB Saunders, Philadelphia, 1717-1762.

2. Weinstein LS, Yu S, Warner DR, Liu J (2001) Endocrine manifestations of stimulatory G protein $\alpha$-subunit mutations and the role of genomic imprinting. Endocr Rev 22: 675-705.

3. Brandi ML, Gagel RF, Angeli A, Bilezikian JP, BeckPeccoz P, Bordi C, Conte-Devolx B, Falchetti A, Gheri RG, Libroia A, Lips CJ, Lombardi G, Mannelli M, Pacini F, Ponder BA, Raue F, Skogseid B, Tamburrano G, Thakker RV, Thompson NW, Tomassetti P, Tonelli F, Wells SA Jr, Marx SJ (2001) Guidelines for diagnosis and therapy of MEN type 1 and 2. J Clin Endocrinol Metab 86: 5658-5671.

4. Hai N, Aoki N, Shimatsu A, Mori T, Kosugi S (2000) Clinical features of multiple endocrine neoplasia type 1 (MEN1) phenocopy without germline MEN1 gene mutations: analysis of 20 Japanese sporadic cases with MEN1. Clin Endocrinol 52: 509-518.

5. Burgess JR, Nord B, David R, Greenaway TM, Parameswaran V, Larsson C, Shepherd JJ, Teh BT (2000) Phenotype and phenocopy: the relationship between genotype and clinical phenotype in a single large family with multiple endocrine neoplasia type 1 (MEN1). Clin Endocrinol 53: 205-211.

6. Allsup DJ, Cawley JC (2002) The diagnosis and treatment of hairy-cell leukemia. Blood Rev 16: 255-262.

7. Sakurai A, Shirahama S, Fujimori M, Katai M, Itakura Y, Kobayashi S, Amano J, Fukushima Y, Hashizume K (1998) Novel MEN1 gene mutations in familial multiple endocrine neoplasia type 1. J Hum Genet 43: 199201.

8. Agarwal SK, Kester MB, Debelenko LV, Heppner C, Emmert-Buck MR, Skarulis MC, Doppman JL, Kim YS, Lubensky IA, Zhuang Z, Green JS, Guru SC, Manickam P, Olufemi SE, Liotta LA, Chandrasekharappa SC, Collins FS, Spiegel AM, Burns AL, Marx SJ (1997) Germline mutations of the MEN1 gene in familial multiple endocrine neoplasia type 1 and related states. Hum Molec Genet 6: 1169-1175.

9. Heppner C, Kester MB, Agarwal SK, Debelenko LV,
Emmert-Buck MR, Guru SC, Manickam P, Olufemi SE, Skarulis MC, Doppman JL, Alexander RH, Kim YS, Saggar SK, Lubensky IA, Zhuang Z, Liotta LA, Chandrasekharappa SC, Collins FS, Spiegel AM, Burns AL, Marx SJ (1997) Somatic mutation of the MEN1 gene in parathyroid tumors. Nat Genet 16: 375378.

10. Gortz B, Roth J, Speel EJ, Krahenmann A, De Krijger RR, Matias-Guiu X, Muletta-Feurer S, Rutmann K, Saremaslani P, Heitz PU, Komminoth P (1999) MEN1 gene mutation analysis of sporadic adrenocortical letions. Int J Cancer 80: 373-379.

11. Sakurai A, Katai M, Itakura Y, Ikeo Y, Hashizume K (1999) Premature centromere division in patients with multiple endocrine neoplasia type 1. Cancer Genet Cytogenet 109: 138-140.

12. Itakura Y, Sakurai A, Katai M, Ikeo Y, Hashizume K (2000) Enhanced sensitivity to alkylating agent in lymphocytes from patients with multiple endocrine neoplasia type 1. Biomed Pharmacother 54: s187-s190.

13. Kishi M, Tsukada T, Shimizu S, Futami H, Ito $\mathrm{Y}$, Kanbe M, Obara T, Yamaguchi K (1998) A large germline deletion of the MEN1 gene in a family with multiple endocrine neoplasia type 1. Jpn J Cancer Res 89: $1-5$.

14. Cavaco BM, Domingues R, Bacelar MC, Cardoso H, Barros L, Gomes L, Ruas MM, Agapito A, Garrao A, Pannett AA, Silva JL, Sobrinho LG, Thakker RV, Leite V (2002) Mutational analysis of Portuguese families with multiple endocrine neoplasia type 1 reveals large germline deletions. Clin Endocrinol 56: 465-473.

15. Schwartz HS, Zimmerman NB, Simon MA, Wroble RR, Millar EA, Bonfiglio M (1987) The malignant potential of enchondromatosis. $J$ Bone Joint Surg: Am 69: 269-274.

16. Marymont JV, Fisher RF, Emde GE (1987) Maffucci's syndrome complicated by carcinoma of the breast, pituitary adenoma, and mediastinal hemangioma. South Med J 80: 1429-1431.

17. Miki K, Kawamoto K, Kawamura Y, Matsumura H, Asada Y, Hamada A (1987) A rare case of Maffucci's syndrome combined with tuberculum sellae enchondroma, pituitary adenoma and thyroid adenoma. Acta 
Neurochir 87: 79-85.

18. Schnall AM, Genuth SM (1976) Multiple endocrine adenomas in a patient with the Maffucci syndrome. Am J Med 61: 952-956.

19. Hopyan S, Gokgoz N, Poon R, Gensure RC, Yu C, Cole WG, Bell RS, Juppner H, Andrulis IL, Wunder JS, Alman BA (2002) A mutant PTH/PTHrP I receptor in enchondromatosis. Nat Genet 30: 306-310.

20. Sambani C, Trafalis DT, Mitsoulis-Mentzikoff C, Poulakidas E, Makropoulos V, Pantelias GE, Mecucci C (2001) Clonal chromosome rearrangements in hairy cell leukemia: personal experience and review of literature. Cancer Genet Cytogenet 129: 138-144.

21. Poisson A, Zablewska B, Gaudray P (2003) Menin interacting proteins as clues toward the understanding of multiple endocrine neoplasia type 1. Cancer Lett 189: $1-10$

22. Chandrasekharappa SC, Teh BT (2003) Functional studies of the MEN1 gene. J Intern Med 253: 606-615.

23. Sowa H, Kaji H, Canaff L, Hendy GN, Tsukamoto T, Yamaguchi T, Miyazono K, Sugimoto T and Chihara $\mathrm{K}$ (2003) Inactivation of menin, the product of the multiple endocrine neoplasia type 1 gene, inhibits the commitment of multipotential mesenchymal stem cells into the osteoblast lineage. J Biol Chem 278: 21058-21069.

24. Jin S, Mao H, Schnepp RW, Sykes SM, Silva AC, D'Andrea AD and Hua X (2003) Menin associates with FANCD2, a protein involved in repair of DNA damage. Cancer Res 63: 4204-4210.

25. Thepot D, Weitzman JB, Barra J, Segretain D, Stinnakre MG, Babinet C, Yaniv M (2000) Targeted disruption of the murine junD gene results in multiple defects in male reproductive function. Development 127: 143-153.

26. Datto MB, Frederick JP, Pan L, Borton AJ, Zhuang Y, Wang XF (1999) Targeted disruption of Smad3 reveals an essential role in transforming growth factor $\beta$-mediated signal transduction. Mol Cell Biol 19: 2495-2504.

27. Sha WC, Liou HC, Tuomanen EI, Baltimore D (1995) Targeted disruption of the p50 subunit of NF-kappa B leads to multifocal defects in immune responses. Cell 80: $321-330$.

28. Tolstonog GV, Shoeman RL, Raub U, Traub P (2001) Role of the intermediate filament protein vimentin in delaying senescence and in the spontaneous immortalization of mouse embryo fibroblasts. DNA Cell Biol 20: 509-529.

29. Pitman JL, Lin TP, Kleeman JE, Erickson GF, MacLeod CL (1998) Normal reproductive and macrophage function in Pem homeobox gene-deficient mice. Dev Biol 202: 196-214.

30. D'Andrea AD, Grompe M (2003) The Fanconi anaemia/BRCA pathway. Nat Rev Cancer 3: 23-34.

31. Shiloh Y (2003) ATM and related protein kinases: safeguarding genome integrity. Nat Rev Cancer 3: 155168 . 